\title{
Snapshot of methanogen sensitivity to temperature in Zoige wetland from Tibetan plateau
}

\author{
Li Fu', Tianze Song ${ }^{2,3}$ and Yahai $L u^{1,3 *}$ \\ ${ }^{1}$ College of Resources and Environmental Sciences, China Agricultural University, Beijing, China \\ 2 School of Life Science, Fudan University, Shanghai, China \\ ${ }^{3}$ College of Urban and Environmental Sciences, Peking University, Beijing, China
}

Edited by:

Paul Bodelier, Netherlands Institute

of Ecology, Netherlands

\section{Reviewed by:}

Xiuzhu Dong, Chinese Academy of

Sciences, China

Kim Yrjälä, University of Helsinki,

Finland

\section{*Correspondence:}

Yahai Lu, College of Urban and

Environmental Sciences, Peking

University, No. 5 Yiheyuan Road,

Beijing 100871, China

e-mail: luyh@pku.edu.cn
Zoige wetland in Tibetan plateau represents a cold environment at high altitude where significant methane emission has been observed. However, it remains unknown how the production and emission of $\mathrm{CH}_{4}$ from Zoige wetland will respond to a warming climate. Here we investigated the temperature sensitivity of methanogen community in a Zoige wetland soil under the laboratory incubation conditions. One soil sample was collected and the temperature sensitivity of the methanogenic activity, the structure of methanogen community and the methanogenic pathways were determined. We found that the response of methanogenesis to temperature could be separated into two phases, a high sensitivity in the low temperature range and a modest sensitivity under mesophilic conditions, respectively. The aceticlastic methanogens Methanosarcinaceae were the main methanogens at low temperatures, while hydrogenotrophic Methanobacteriales, Methanomicrobiales, and Methanocellales were more abundant at higher temperatures. The total abundance of $m c r A$ genes increased with temperature indicating that the growth of methanogens was stimulated. The growth of hydrogenotrophic methanogens, however, was faster than aceticlastic ones resulting in the shift of methanogen community. Determination of carbon isotopic signatures indicated that methanogenic pathway was also shifted from mainly aceticlastic methanogenesis to a mixture of hydrogenotrophic and aceticlastic methanogenesis with the increase of temperature. Collectively, the shift of temperature responses of methanogenesis was in accordance with the changes in methanogen composition and methanogenic pathway in this wetland sample. It appears that the aceticlastic methanogenesis dominating at low temperatures is more sensitive than the hydrogenotrophic one at higher temperatures.

Keywords: methanogenesis, methanogens, temperature sensitivity, Zoige wetland, Tibetan plateau

\section{INTRODUCTION}

The temperature sensitivity of soil microbial activity has gained increasing attention in recent decades (Davidson and Janssens, 2006). The global surface temperature is expected to increase by $3.7-4.8^{\circ} \mathrm{C}$ by the year 2100 (IPCC: Climate Change, 2014). Understanding the response of soil microbial activity is imperative to predict the feedback of global climate change. Low temperature has been a major constraint to the degradation of organic matter in high latitude and high altitude regions, where large amounts of readily degradable organic carbon have been stored (Davidson and Janssens, 2006; Liu et al., 2011). These regions, however, are warming rapidly. Temperature sensitivity of soil microbial activity is critical to the vulnerability of carbon stocks in these areas.

Temperature sensitivity of soil respiration has been estimated recently using meta-analysis and modeling. Based on the published data, Bond-Lamberty and Thomson (2010) obtained the mean temperature dependence of terrestrial respiration $\left(\mathrm{Q}_{10}\right)$ of 1.5. Temperature sensitivity might be influenced by environmental and biological factors such as microbial community structure and substrate availability. Mahecha et al. (2010) derived the so-called intrinsic temperature dependences, and showed an almost universal $\mathrm{Q}_{10}$ value $(1.4 \pm 0.1)$ for ecosystems ranging from croplands to mixed forests and woody savanna. Similarly, Yvon-Durocher et al. (2012) reported that the sensitivity of ecosystem respiration to seasonal changes in temperature was statistically indiscernible across environments from aquatic to terrestrial ecosystems. The reconciled temperature sensitivity was also revealed for methanogenic systems from pure cultures to natural ecosystems (Yvon-Durocher et al., 2014). Thus, the meta-analysis and modeling indicated a remarkable consistency in temperature sensitivity of either terrestrial respiration or methanogenesis. This contrasts strikingly with the huge diversity of microbiota and their metabolisms contained in terrestrial ecosystems (Karhu et al., 2014).

Cold wetlands including boreal and alpine fens are among the most important biogenic sources of atmospheric methane (Conrad, 2009; Kirschke et al., 2013). To understand and predict the production and emission of $\mathrm{CH}_{4}$, numerous studies have been conducted in these areas to determine the spatiotemporal patterns of $\mathrm{CH}_{4}$ fluxes and the structure and function of methanogenic archaeal communities (e.g., Yrjala et al., 2011; Godin et al., 2012; 
Yang et al., 2014). The key factors controlling methanogenic activity have been identified that include temperature, water level, vegetation, surface topography, substrate availability, soil $\mathrm{pH}$ and depth (Galand et al., 2002, 2003, 2005; Høj et al., 2008; Juottonen et al., 2008; Tian et al., 2012a,b). Temperature stands out among the most important factors (Høj et al., 2008; Juottonen et al., 2008). Quantitative characterization of temperature sensitivity of methanogenic activity, however, is rare. Zoige wetland is an open fen located in Tibetan plateau with the average altitude of $3500 \mathrm{~m}$, mean annual temperature of around $1{ }^{\circ} \mathrm{C}$ and mean annual precipitation of $650 \mathrm{~mm}$; it covers a total area of $6180 \mathrm{~km}^{2}$ (Chen et al., 2009a,b). The vegetation was dominated by Carex muliensis and Eleocharis valleculosa (Cai et al., 1965). Despite the cold climate, it has been estimated that the mean annual emission of $\mathrm{CH}_{4}$ amounts to $0.65-1.0 \mathrm{Tg}$, accounting for about one third of total emissions from natural wetlands in China (Chen et al., 2013a,b). Similar as in boreal fens and high arctic peats (Høj et al., 2008; Juottonen et al., 2008), temperature has been identified as the major factor controlling the seasonal and annual $\mathrm{CH}_{4}$ emissions from Zoige wetland (Chen et al., 2009b, 2013a). Investigation of methanogen community revealed the prevalence of psychrophilic aceticlastic and methylotrophic methanogens in Zoige wetland (Zhang et al., 2008b). For instance, a methanolutilizing pure culture isolated from this wetland, Methanolobus psychrophilus, showed the optimum growth at $18^{\circ} \mathrm{C}$, being active down to $0^{\circ} \mathrm{C}$ but stopped growth at $25^{\circ} \mathrm{C}$ (Zhang et al., 2008a). Apparently, the significant emission of $\mathrm{CH}_{4}$ is related to the existence of cold-adapted methanogens in this wetland. It, however, remains unknown how the methanogen community and methanogenesis in Zoige wetland will respond to a warming climate.

The investigations in rice field soils have shown that the methanogen community shifted from a mixture of aceticlastic and hydrogenotrophic methanogens under mesophilic conditions to the dominance of hydrogenotrophic Methanocellales at above $40^{\circ} \mathrm{C}$ (Fey and Conrad, 2000; Peng et al., 2008; Rui et al., 2011) or to the dominance of aceticlastic Methanosaetaceae and Methanosarcinaceae when temperature decreases to $15^{\circ} \mathrm{C}$ (Chin et al., 1999; Conrad et al., 2009). A preliminary study in Zoige wetland also showed the change in composition of methanogens and the pathway of methanogenesis between 15 and $30^{\circ} \mathrm{C}$ (Zhang et al., 2008a). We hypothesized that a shift in methanogenic community could induce change in temperature sensitivity of $\mathrm{CH}_{4}$ production in Zoige wetland. The purpose of the present study, therefore, was to determine the effects of temperature on methanogen composition and methanogenic activity and to evaluate if the temperature sensitivity of $\mathrm{CH}_{4}$ production in Zoige wetland was related with changes in methanogen community and methanogenic pathway. A laboratory incubation experiment was conducted with a soil sample collected from Zoige wetland. The incubations under different temperatures allowed us to explicitly link the sensitivity of methanogenic activity to the structure of methanogen community and the methanogenic pathways.

\section{EXPERIMENTAL METHODS}

\section{SOIL SAMPLING AND ANAEROBIC INCUBATION}

The soil sample was collected from an open fen close to the Wetland National Nature Reserve of Zoige located in
Qinghai-Tibetan Plateau $\left(33^{\circ} 47^{\prime} \mathrm{N}, 102^{\circ} 57^{\prime} \mathrm{E}\right)$. The sampling site is covered dominantly by Carex muliensis. The soil is flooded periodically depending on precipitation and meltwater runoff. The microtopography consists of hummocks and hollows. The water table level was about $5 \mathrm{~cm}$ below the hollow surface at the time of sampling. Soil samples were collected on 25 July 2012 in about a square meter area at the depth of $5-20 \mathrm{~cm}$ below the hollow surface. Vegetation and organic debris was removed by hands during the sampling. About 10 kilograms of wet soil samples were placed in an ice box and transported to the laboratory within $24 \mathrm{~h}$ for immediate processing. The soil sample had the following characteristics: $\mathrm{pH} 7.5$, organic $\mathrm{C}$ of $152.6 \mathrm{~g} \mathrm{~kg}^{-1}$, total $\mathrm{N}$ of $10.6 \mathrm{~g} \mathrm{~kg}^{-1}$, and $\mathrm{C}: \mathrm{N}$ of 14.4 . Soil slurries were prepared by mixing soil samples with autoclaved and degassed water. The slurries were passed through 2-mm sieves to homogenize and remove the coarse materials. Thirty grams of soil slurry was filled into $50-\mathrm{ml}$ glass bottles with the final soil (d.w.) to water ratio of 1:3.5. The bottles were closed with butyl stoppers and flushed with $\mathrm{N}_{2}$. Soil slurries were incubated for 81 days at $10^{\circ} \mathrm{C}, 15^{\circ} \mathrm{C}, 20^{\circ} \mathrm{C}, 25^{\circ} \mathrm{C}$, $30^{\circ} \mathrm{C}$, and $35^{\circ} \mathrm{C}$, respectively. Each temperature treatment was carried out in triplicate.

\section{MEASUREMENT OF GASES AND VOLATILE FATTY ACIDS}

Gas samples $(0.1 \mathrm{ml})$ were taken from headspace with a pressurelock precision analytical syringe (Baton Rouge, LA, USA). The concentrations of $\mathrm{CH}_{4}, \mathrm{CO}_{2}$, and $\mathrm{H}_{2}$ were analyzed using gas chromatographs GC-7890 (Agilent Technologies, USA) equipped with a thermal conductivity detector. The ${ }^{13} \mathrm{C}$ abundance $\left({ }^{13} \mathrm{C}\right)$ of $\mathrm{CH}_{4}$ and $\mathrm{CO}_{2}$ was analyzed by a gas chromatographyisotope ratio mass spectrometry system (Yuan and Lu, 2009). Liquid samples $(0.5 \mathrm{ml})$ were taken with sterile syringes and centrifuged $15 \mathrm{~min}$ at $17,949 \times g$ at $4^{\circ} \mathrm{C}$. The supernatant was collected, passed through $0.25-\mu \mathrm{m}$-pore-size filters, and stored at $-20^{\circ} \mathrm{C}$. Acetate and propionate were analyzed with an HPLC1200 using a Zorbax SB-AQ C18 column (Agilent Technologies, USA).

Temperature sensitivity was calculated according to the Arrhenius equation:

$$
\ln \mathrm{P}=\mathrm{E}(-1 / \mathrm{RT})+\mathrm{M}
$$

where $\mathrm{P}$ is the rate of $\mathrm{CH}_{4}$ production, $\mathrm{E}$ is the activation energy $(\mathrm{eV}), \mathrm{T}$ is the absolute temperature $(\mathrm{K}), \mathrm{R}$ is the Boltzmann constant $\left(8.623 \times 10^{-5} \mathrm{eV} \mathrm{K}^{-1}\right)$, and $\mathrm{M}$ is the theoretical rate of $\mathrm{CH}_{4}$ production in the absence of activation energy. The maximal rate of $\mathrm{CH}_{4}$ production was obtained from the cumulating curve of $\mathrm{CH}_{4}$ partial pressure in the headspace of incubation bottles. To incorporate enzyme concentration into the calculation, the maximal rates of $\mathrm{CH}_{4}$ production were normalized against the total abundances of $m c r A$ that were quantified by real time PCR as described below.

\section{NUCLEIC ACID EXTRACTION AND PURIFICATION}

The total DNA of soil samples was extracted using the protocol by Ma et al. (2012). Briefly, $2 \mathrm{~g}$ of soil slurry was extracted sequentially with TPMS buffer (50 mM Tris- $\mathrm{HCl}$ [pH 7.0], 1.7\% [wt/vol] polyvinylpyrrolidone $\mathrm{K} 25,20 \mathrm{mM} \mathrm{MgCl}_{2}, 1 \%$ [wt/vol] sodium dodecyl sulfate) and phenol-based lysis buffer $(5 \mathrm{mMTris}-\mathrm{HCl}$ 
[pH 7.0], $5 \mathrm{mM} \mathrm{Na} 2$ EDTA, 1\% [wt/vol] sodium dodecyl sulfate, $6 \%$ [vol/vol] water-saturated phenol). Beads-beating was performed in FastPrep-24 (MP Biomedicals, USA). The supernatants were further extracted with water-saturated phenol, phenol-chloroform-isoamyl alcohol (25:24:1 [vol/vol/vol]), and chloroform-isoamyl alcohol $(24: 1$ [ $\mathrm{vol} / \mathrm{vol}])$. The extracts were purified by cold ethanol and sodium acetate. The quality and purity of DNA were checked by $1 \%$ agarose gel electrophoresis and NanoDrop1000 spectrophotometry (NanoDrop Technologies, Wilmington, DE).

\section{TERMINAL RESTRICTION FRAGMENT LENGTH POLYMORPHISM (T-RFLP) ANALYSIS}

PCR amplification and terminal restriction fragment polymorphism (T-RFLP) analyses of archaeal 16S rRNA gene fragments followed the protocols described in Peng et al. (2008). PCR was carried out using the primer set Ar109f and Ar915r (Lueders et al., 2004). The $5^{\prime}$ end of the Ar915r primer was labeled with 6 -carboxyfluorescein. The $50-\mu 1$ reaction mixture contained $1 \mu \mathrm{l}$ of DNA template (in 1:100 dilution of original extracts), $5 \mu 1$ of $10 \times$ buffer, $3 \mu \mathrm{l}$ of $25 \mathrm{mM} \mathrm{MgCl}_{2}, 1 \mu \mathrm{l}$ of a $10 \mathrm{mM}$ concentration of the deoxynucleoside triphosphates, $0.5 \mu \mathrm{l}$ of each primer $(50 \mu \mathrm{M})$, and $2.5 \mathrm{U}$ of Tag DNA polymerase (TaKaRa). The thermal profile was as follows: $3 \mathrm{~min}$ at $94^{\circ} \mathrm{C} ; 32$ cycles of $60 \mathrm{~s}$ at $94^{\circ} \mathrm{C}, 45 \mathrm{~s}$ at $52^{\circ} \mathrm{C}$, and $90 \mathrm{~s}$ at $72^{\circ} \mathrm{C}$; and finally $5 \mathrm{~min}$ at $72^{\circ} \mathrm{C}$. The PCR product was purified using an agarose gel DNA extraction kit (TaKaRa) and digested at $65^{\circ} \mathrm{C}$ for $3.5 \mathrm{~h}$ by TaqI (Fermentas, Canada). The digestion products were purified with SigmaSpin Post-Reaction Clean-Up Columns (Sigma), and a portion was mixed with deionized formamide and the internal standard GeneScan-1000 LIZ (Applied Biosystems). The mixtures were denatured for $3 \mathrm{~min}$ at $95^{\circ} \mathrm{C}$, and the DNA fragments were size separated using a $3730 \times 1$ Genetic Analyzer (Applied Biosystems). The percent abundance (Ap) of individual terminal restriction fragments (T-RFs) were calculated as the percentage of each peak height in the sum of all peak heights in a given T-RFLP profile and only those T-RFs with $A p>1 \%$ were considered in further analyses (Noll et al., 2005).

\section{CLONING, SEQUENCING, AND PHYLOGENIC ANALYSIS}

Three clone libraries of the archaeal 16S rRNA genes were constructed from soil slurries incubated 49 days at $15^{\circ} \mathrm{C}, 25^{\circ} \mathrm{C}$, and $35^{\circ} \mathrm{C}$, respectively. The PCR amplification used the same primers as indicated above without FAM labeling. PCR products were purified and ligated into the pMD19-T vector (TaKaRa) according to the manufacturer's instructions. Plasmids were transformed into E. coli cells, and more than 100 clones were randomly selected from each clone library and sequenced with an ABI $3730 \times 1$ sequencer using BigDye Terminator cycle sequencing chemistry (Applied Biosystems) (Peng et al., 2008; Rui et al., 2009). Rarefaction curves (Figure S1) were calculated for three clone libraries according to the method described by Schloss and Handelsman (2005). Coverage of each clone library was calculated according to methods described by Good (1953) using the formula $[1-(\mathrm{n} 1 / \mathrm{N})] \times 100(n 1$ and $\mathrm{N}$ denote the number of sole OTUs and total number of clones in a library, respectively). The coverage of analyzed clones by phylotype-richness estimates were 89,92 , and $81 \%$ for $15^{\circ} \mathrm{C}, 25^{\circ} \mathrm{C}$, and $35^{\circ} \mathrm{C}$ treatment respectively, indicating that the clone libraries were adequately examined. Phylogenetic trees were constructed using the neighbor-joining algorithm according to the protocol of
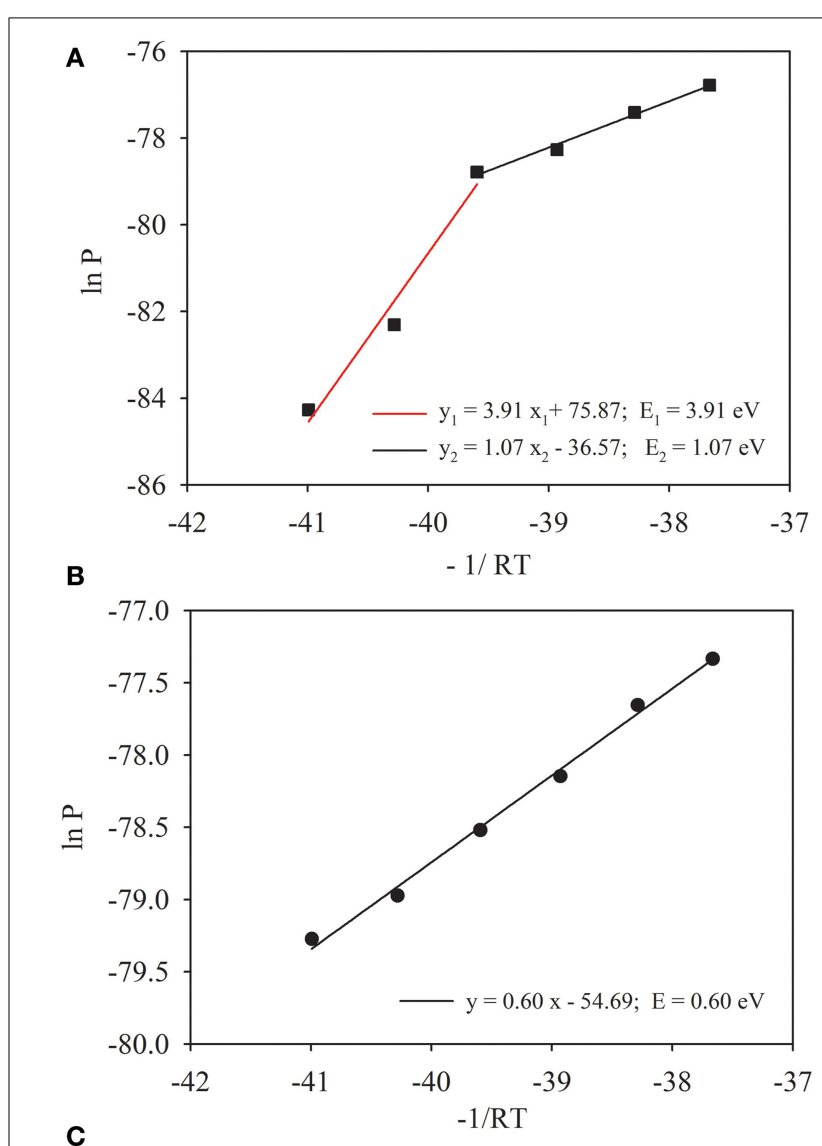

C

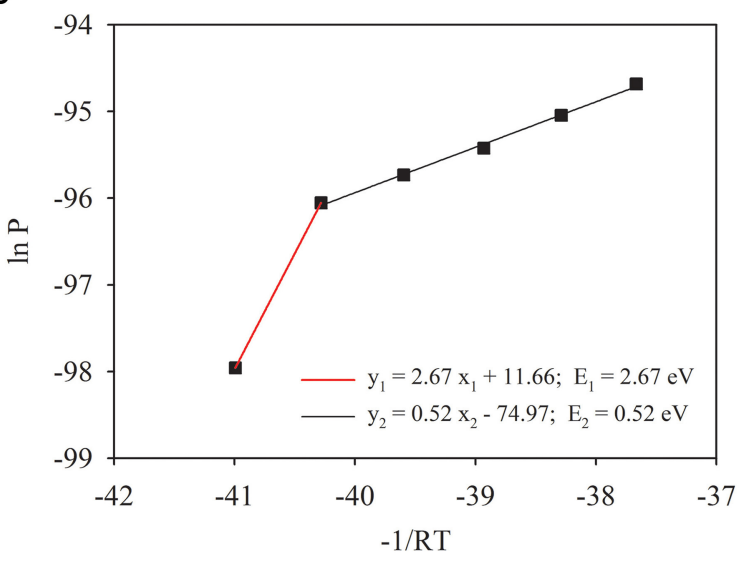

FIGURE 1 | Temperature dependences of $\mathrm{CH}_{4}$ (A) and $\mathrm{CO}_{2}$ (B) production in Zoige wetland. Temperature dependence was characterized through plotting Arrhenius equation with "InP" as a function of "-1/RT," where $\mathrm{P}$ is the maximal rate of $\mathrm{CH}_{4}$ production, $\mathrm{T}$ is the absolute temperature and $\mathrm{R}$ is the Boltzmann constant $\left(8.623 \mathrm{NU} \times 10^{-5} \mathrm{eV} \mathrm{K}^{-1}\right)$. To take into account the effect of enzyme abundance, the maximal rate of $\mathrm{CH}_{4}$ production was normalized against the abundance of mcrA (C). Solid lines [except the red line in $\mathbf{( C )}$ ] are the regression fits, where the slope indicates the apparent activation energy $\mathrm{E}(\mathrm{eV})$. 
Lueders and Friedrich (2000), and bootstrap analysis implemented 1000 replicates.

\section{QUANTITATIVE (REAL-TIME) PCR ANALYSIS}

Quantitative PCR of $m c r A$ genes were carried out in a 7500 realtime PCR system (Applied Biosystems) using the primer pair mlas and mcrA-rev (Steinberg and Regan, 2008). Quantitative PCR was performed in a total volume of $25 \mu \mathrm{l}$ containing $12.5 \mu \mathrm{l}$ of Power SYBRsGreen PCR Master mix kit (Applied Biosystems), $0.75 \mu \mathrm{l}(10 \mu \mathrm{M})$ primers, $200 \mathrm{ng}$ bovine serum albumin and $2 \mu \mathrm{l}$ of a 100:1 dilution of DNA sample. The thermal cycles and fluorescence signal acquisition followed the protocols described in (Steinberg and Regan, 2008). The DNA standards were prepared from the cloned sequence of $m c r A$ gene, which were further amplified with vector-specific primers. The PCR products were purified with a UNIQ-10 column kit (Sangon Biotech, Shanghai, China). The obtained PCR products were quantified using the PicoGreen dsDNA quantification kit (Invitrogen, Eugene, OR) and then converted into the copy number of DNA molecules per unit volume ranging from $1.0 \times 10^{3}$ to $1.0 \times 10^{8}$ copies $\mu \mathrm{l}^{-1}$. Three replicates of each measurement were done.

\section{NUCLEOTIDE SEOUENCE ACCESSION NUMBERS}

The sequences of the 16S rRNA clones obtained in this study have been deposited in the EMBL nucleotide sequence database under the following accession numbers: KJ644784-KJ645071.

\section{RESULTS}

\section{TEMPERATURE SENSITIVITY OF METHANOGENESIS}

Production of $\mathrm{CH}_{4}$ showed a lag phase that increased with the decrease of temperature (Figure S2). Emission of $\mathrm{CO}_{2}$ into the headspace, however, occurred immediately in all incubations. Accumulation of $\mathrm{CH}_{4}$ in the headspace increased markedly with the increase of temperature. We calculated the rate of $\mathrm{CH}_{4}$ production at each incubation temperature (Figure S3). The rate reached to maxima around 20 days at $30^{\circ} \mathrm{C}$ and $35^{\circ} \mathrm{C}$, but delayed substantially at lower temperatures. The maximal rates corresponded roughly to substrate availability inferred from the dynamics of acetate and propionate in incubations (Figure S4). Based on maximal rates of $\mathrm{CH}_{4}$ production, we calculated the activation energy of methanogenesis according to Arrhenius equation (Figure 1). It revealed that the temperature sensitivity could be separated into two phases with the first activation energy of $1.07 \mathrm{eV}$ between $20^{\circ} \mathrm{C}$ and $35^{\circ} \mathrm{C}$ and the second $3.91 \mathrm{eV}$ at lower temperatures (Figure 1A). Similar calculation produced only a single value $(0.60 \mathrm{eV})$ for production of $\mathrm{CO}_{2}$ across the temperature range tested (Figure 1B). Since temperature dependence could be influenced by enzyme concentration, we quantified $m c r A$ (Table 1), the gene encoding the subunit A of methyl coenzyme-M reductase that metabolized the last step of $\mathrm{CH}_{4}$ production. The activation energy was recalculated using the maximal rates of $\mathrm{CH}_{4}$ production normalized against the maximal abundance of $m c r A$. The pattern of temperature dependences did not change, i.e., showing two phases of temperature sensitivity (Figure 1C). The values of activation energy, however, decreased to $0.52 \mathrm{eV}$ in upper temperature range $\left(15-35^{\circ} \mathrm{C}\right)$ and $2.67 \mathrm{eV}$ in lower temperature range $\left(<15^{\circ} \mathrm{C}\right)$.

\section{COMMUNITY STRUCTURE AND METHANOGENIC PATHWAY}

Methanogen community was analyzed by using cloning, sequencing and T-RFLP analysis of the archaeal 16S rRNA genes. Three hundreds of $16 \mathrm{~S}$ rRNA clones were retrieved from slurries incubated 49 days at $15^{\circ} \mathrm{C}, 25^{\circ} \mathrm{C}$, and $35^{\circ} \mathrm{C}$, respectively. The phylogenetic analysis of clone sequences showed that the archaeal community consisted of Methanosarcinaceae, Methanosaetaceae, Methanocellales, Methanomicrobiaceae, Methanobacteriaceae, and the uncultured euryarchaeotal RC-III, RC-V, LDS cluster and the crenarchaeotal group $1.1 \mathrm{~b}$ and group 1.3 (Figure 2). The crenarchaeotal group $1.1 \mathrm{~b}$ dominated accounting for over $40 \%$ of total archaeal clones (Figure S5). The relative abundances of methanogens and LDS cluster, however, increased relatively at $25^{\circ} \mathrm{C}$ and $35^{\circ} \mathrm{C}$, while that of crenarchaeotal group $1.1 \mathrm{~b}$ decreased.

T-RFLP profiles of archaeal 16S rRNA genes revealed that the 185-bp T-RF was predominant at the beginning and it remained dominant throughout the incubation at $10^{\circ} \mathrm{C}$ and $15^{\circ} \mathrm{C}$ (Figure 3 ). The relative abundance of this T-RF, however, decreased with incubation at higher temperatures. In contrast, the relative abundance of the 91-bp and 392-bp T-RFs increased over time in the incubations at $20^{\circ} \mathrm{C}$ and above. In silico analysis of clone sequences indicated that the 185bp T-RF was related to Methanosarcinaceae and crenarchaeotal group 1.1b; the 91-bp T-RF to Methanobacteriaceae and LDS cluster, and the 392-bp T-RF to Methanomicrobiaceae and Methanocellales (Figure 2). Thus, the analyses of T-RFLP and clone sequences indicated that Methanosarcinaceae (185 bp) dominated the methanogen community at $10^{\circ} \mathrm{C}$ and $15^{\circ} \mathrm{C}$, while the hydrogenotrophic methanogens Methanobacteriales (91 bp),

Table 1 | Temperature and time dependent total $\operatorname{mcr} A$ gene abundances ${ }^{\mathrm{a}}$.

\begin{tabular}{lccccccc}
\hline & Days & \multicolumn{9}{c}{ Temperature $\left({ }^{\circ} \mathbf{C}\right)$} \\
\cline { 3 - 7 } & & $\mathbf{1 0}$ & $\mathbf{1 5}$ & $\mathbf{2 0}$ & $\mathbf{2 5}$ & $\mathbf{3 0}$ \\
\hline marA $\left(\times 10^{6}\right.$ copies $)$ & 3 & ND & ND & ND & ND & ND & ND \\
& 24 & ND & ND & ND & $0.17 \pm 0.02$ & $7.61 \pm 1.14$ & $6.12 \pm 1.15$ \\
& 49 & $0.50 \pm 0.04$ & $0.46 \pm 0.17$ & $1.36 \pm 0.21$ & $0.52 \pm 0.09$ & $6.29 \pm 1.62$ & $7.50 \pm 1.37$ \\
& 65 & $0.49 \pm 0.05$ & $0.50 \pm 0.12$ & $3.50 \pm 0.24$ & $25.13 \pm 1.66$ & $45.52 \pm 1.72$ & $59.42 \pm 9.30$ \\
& 81 & $0.88 \pm 0.24$ & $0.93 \pm 0.29$ & $22.9 \pm 2.72$ & $28.31 \pm 6.93$ & $17.29 \pm 2.86$ & $55.37 \pm 16.41$ \\
\hline
\end{tabular}

${ }^{a}$ Values are means \pm standard errors $(n=3) ; N D$ means not detected. 


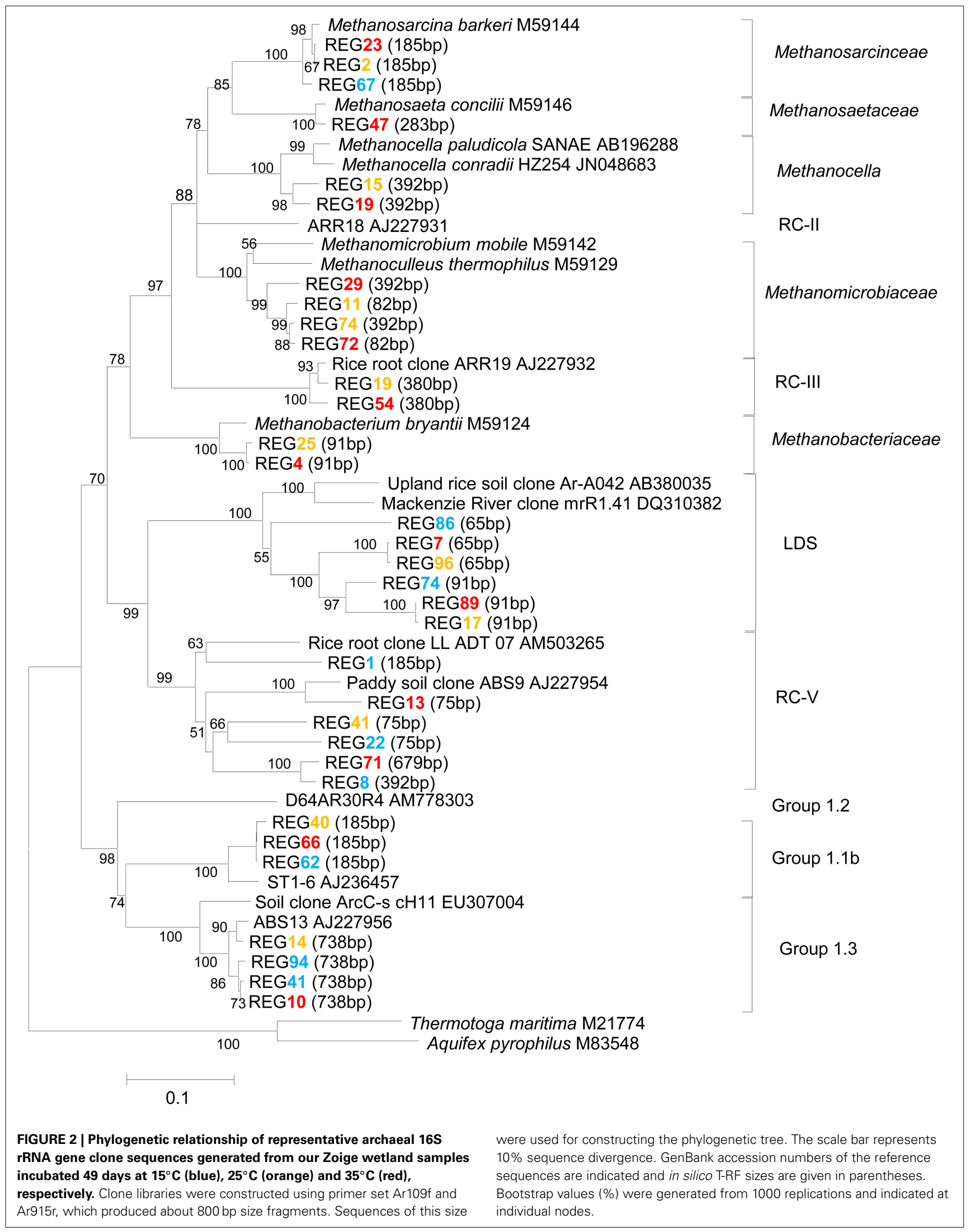



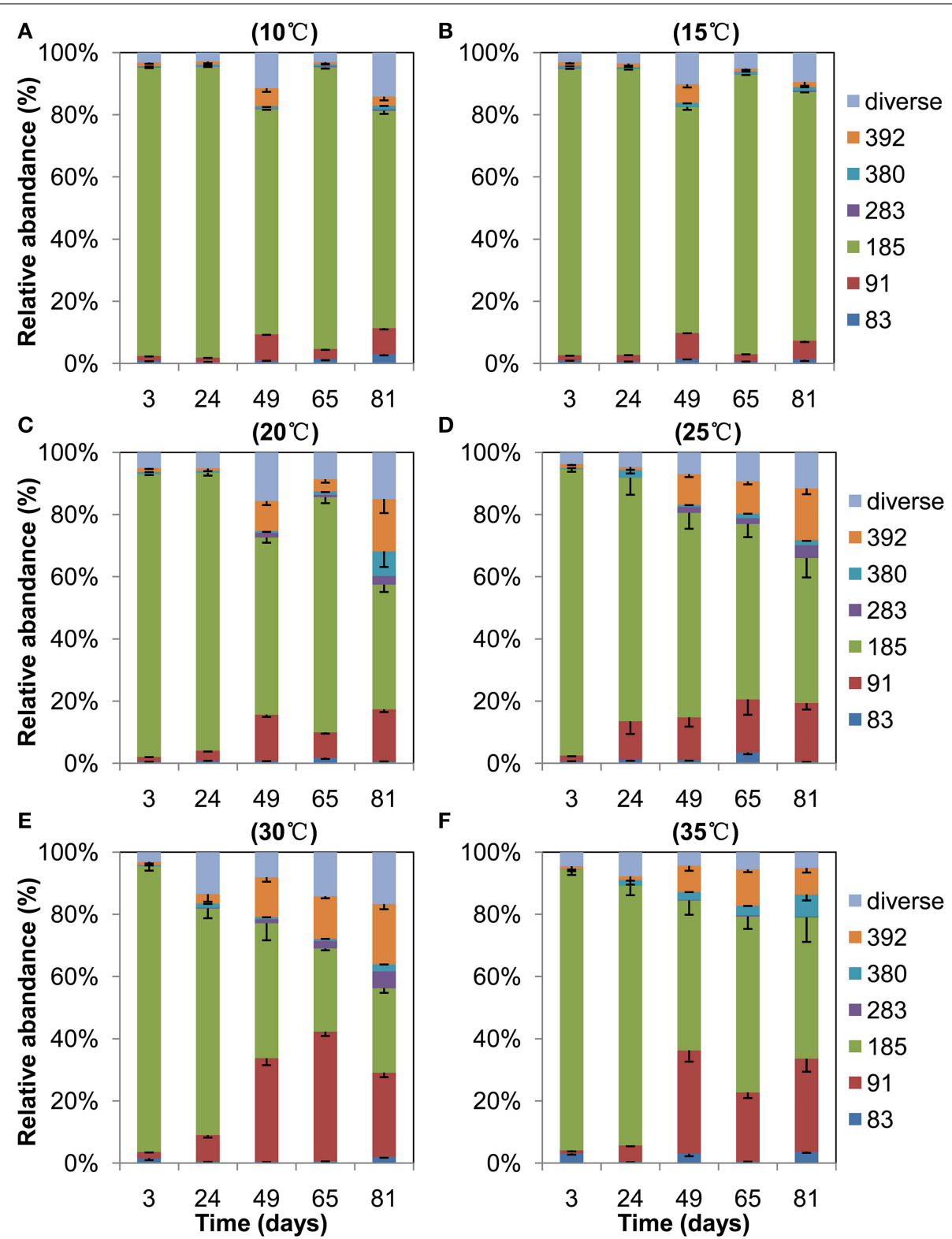

FIGURE 3 | T-RFLP profiles of the archaeal community in anaerobically incubated Zoige wetland soil at $10^{\circ} \mathrm{C}(\mathrm{A}), 15^{\circ} \mathrm{C}(\mathrm{B}), 20^{\circ} \mathrm{C}(\mathrm{C}), 25^{\circ} \mathrm{C}(\mathrm{D}), 30^{\circ} \mathrm{C}(\mathrm{E})$, and $35^{\circ} \mathbf{C}(\mathbf{F})$, respectively. Data are means minus standard error $(n=3)$. Only major T-RFs are shown, the minor T-RFs are combined as Diverse.

Methanomicrobiales and Methanocellales (392 bp) increased when temperature increased to $20^{\circ} \mathrm{C}$ and above. The total abundance of $m c r A$ increased with the increase of temperature (Table 1), indicating that the growth of methanogens was stimulated. Apparently, the growth of hydrogenotrophic methanogens was faster than aceticlastic ones, resulting in the shift of methanogen community.

To determine if the pathway of $\mathrm{CH}_{4}$ production was altered by temperature, we analyzed the $\delta^{13} \mathrm{C}$ abundances of $\mathrm{CH}_{4}$ and $\mathrm{CO}_{2}$ in incubations at $15^{\circ} \mathrm{C}, 25^{\circ} \mathrm{C}$ and $35^{\circ} \mathrm{C}$, respectively (Figure 4). It is known that $\mathrm{CH}_{4}$ produced from $\mathrm{CO}_{2}$ reduction is more depleted in $\delta^{13} \mathrm{C}$ compared with $\mathrm{CH}_{4}$ produced from acetate cleavage (Conrad et al., 2009). The relative contribution of hydrogenotrophic versus aceticlastic methanogenesis, thus, can be inferred from isotopic signatures. We found that the $\delta^{13} \mathrm{C}$ values of $\mathrm{CH}_{4}$ were between -60 and $-70 \%$ at $25^{\circ} \mathrm{C}$ and $35^{\circ} \mathrm{C}$ after day 20 when $\mathrm{CH}_{4}$ production was most active, while the values at $15^{\circ} \mathrm{C}$ were much higher (Figure 4A). In correspondence, the $\delta^{13} \mathrm{C}$ value of $\mathrm{CO}_{2}$ increased slightly in incubations at $25^{\circ} \mathrm{C}$ and $35^{\circ} \mathrm{C}$, but showed decreasing tendency at $15^{\circ} \mathrm{C}$. The apparent isotopic fractionation factor $\left[\alpha_{\text {app }}=\left(\delta^{13} \mathrm{CO}_{2}+10^{3}\right) /\left(\delta^{13} \mathrm{CH}_{4}+10^{3}\right)\right]$ showed a gradual increase from 1.04 to 1.06 in incubations at $25^{\circ} \mathrm{C}$ and $35^{\circ} \mathrm{C}$, but remaining lower than 1.03 over the incubation at $15^{\circ} \mathrm{C}$ (Figure 4B). The $\alpha_{\text {app }}$ value of 1.04 is characteristic typically for $\mathrm{CH}_{4}$ production from both $\mathrm{CO}_{2}$ and acetate (Conrad et al., 2009). The decrease of $\delta^{13} \mathrm{C}$ values of $\mathrm{CH}_{4}$ and the increase 


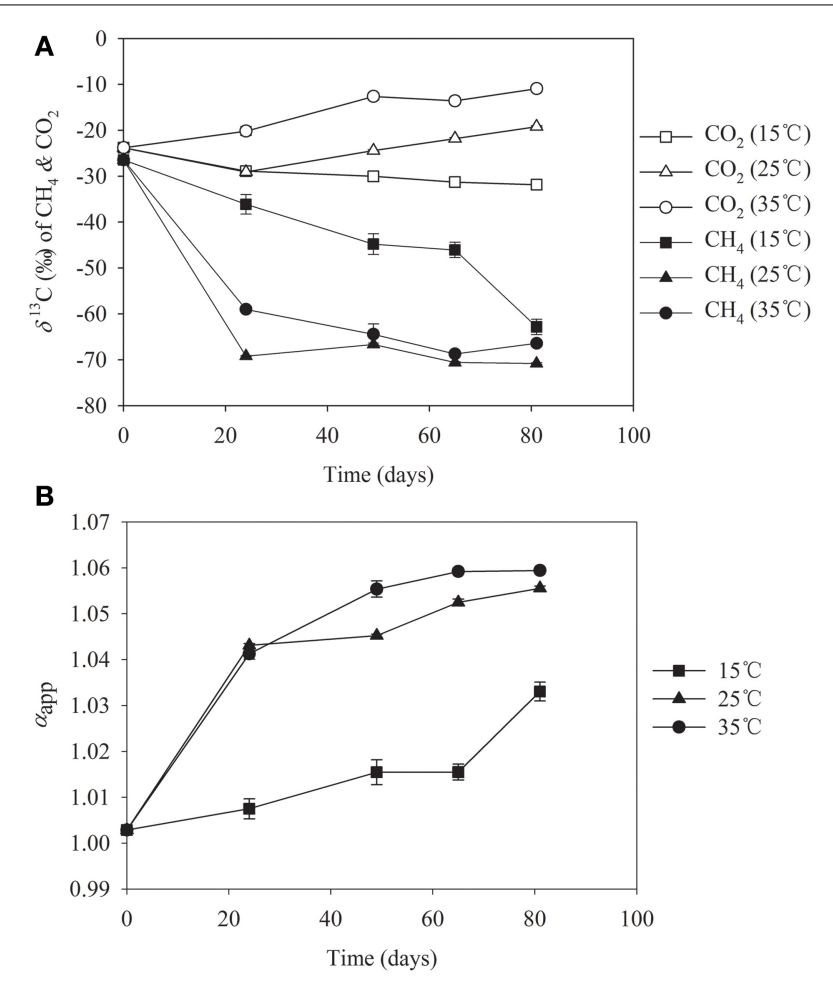

FIGURE $4 \mid \delta^{13} \mathrm{C}$ values of $\mathrm{CO}_{2}$ and $\mathrm{CH}_{4}(\mathrm{~A})$ and the apparent fractionation factor $\left(\alpha_{a p p}\right)(B)$ in slurries of Zoige wetland incubated at $15^{\circ} \mathrm{C}(\square), 25^{\circ} \mathrm{C}(\nabla)$, and $35^{\circ} \mathrm{C}(\bullet)$, respectively.

of $\alpha_{\text {app }}$ at high temperatures indicate that more of $\mathrm{CH}_{4}$ was produced from $\mathrm{CO}_{2}$ reduction. The $\delta^{13} \mathrm{C}$ data, therefore, indicated that methanogenic pathway shifted from the aceticlastic methanogenesis at $15^{\circ} \mathrm{C}$ to a mixture of both hydrogenotrophic and aceticlastic methanogenesis at $25^{\circ} \mathrm{C}$ and $35^{\circ} \mathrm{C}$. This shift was in coincidence with the change in methanogen community as described above.

\section{DISCUSSION}

We showed here that temperature sensitivity of $\mathrm{CH}_{4}$ production in a Tibetan wetland soil sample changed with temperature. Specifically, two phases of temperature dependence can be distinguished, a high sensitivity in the low temperature range $\left(<15^{\circ} \mathrm{C}\right)$ and a modest sensitivity under mesophilic conditions. This change of temperature sensitivity was in accordance with the shifts of methanogen composition and methanogenic pathway. It appeared that the sensitivity of aceticlastic methanogenesis was greater than that of hydrogenotrophic methanogenesis. The temperature sensitivity of methanogenesis revealed in the present experiment was in contrast to the meta-analysis and modeling that showed a universal temperature dependence of methane production across different systems (Yvon-Durocher et al., 2014). It, however, was in line with the finding that the temperature sensitivity differed markedly between photosynthesis, respiration and methanogenesis (Macdonald et al., 1998; Van Hulzen et al., 1999; Hartley et al., 2006; Zou and Gao, 2013), which indicated the dependence of temperature sensitivity on metabolic mechanisms.
Temperature sensitivity was known to be influenced by substrate availability and enzyme concentration (Davidson and Janssens, 2006). We used the maximal rate of $\mathrm{CH}_{4}$ production to reduce the influence of substrate availability. The obtained sensitivity $(1.07 \mathrm{eV})$ at the upper temperature range $\left(20-35^{\circ} \mathrm{C}\right)$ was close to that derived from the meta-analysis (Yvon-Durocher et al., 2014). But when the enzyme factor (i.e., methanogen biomass) was incorporated, a much lower sensitivity $(0.52 \mathrm{eV})$ was obtained. This difference was apparently due to the growth of methanogen populations with increasing temperature. The seasonal change (growth) in methanogen populations has been often observed in various ecosystems (He et al., 2014; Kanta Gaihre et al., 2014; Sabrekov et al., 2014; Wei et al., 2014). To obtain the intrinsic temperature dependence, the growth of methanogens should be taken into account.

In contrast to $\mathrm{CH}_{4}$ production, $\mathrm{CO}_{2}$ production showed a single sensitivity factor over the temperature range tested. This pattern and the activation energy $(0.60 \mathrm{eV})$ were in agreement with previous predictions from the meta-analysis (Yvon-Durocher et al., 2012). One possibility might be that the metabolic mechanisms for $\mathrm{CO}_{2}$ production did not change with temperature. Cautions, however, have to be taken with this explanation, because the mechanisms for $\mathrm{CO}_{2}$ production in anoxic slurries are complicated and remain unclear, and in addition $\mathrm{CO}_{2}$ in the headspace is in equilibrium with liquid that is controlled by slurry $\mathrm{pH}$. We did not measure slurry $\mathrm{pH}$ and hence the effect of chemical equilibrium was not counted.

We found a very high sensitivity of $\mathrm{CH}_{4}$ production in low temperature range. The methanogen community was dominated by Methanosarcinaceae at these temperatures. Members of Methanosarcina are substrate-versatile, using acetate, hydrogen and methylated $\mathrm{Cl}$ compounds for methanogenesis. The ${ }^{13} \mathrm{C}$ signatures of $\mathrm{CH}_{4}$ and $\mathrm{CO}_{2}$, however, indicated that it was the aceticlastic pathway that dominated methanogenesis at low temperatures. At higher temperatures, the relative abundance of hydrogenotrophic methanogens, consisting of Methanobacteriales, Methanomicrobiales and Methanocellales, increased. We did not detect Methanomicrobiales-like Fen Cluster as observed often in acidic boreal fens (Galand et al., 2005; Juottonen et al., 2008). This was probably due to the neutral condition ( $\mathrm{pH}$ 7.5) in our wetland soil sample. Despite different compositions, the shifting pattern of methanogen community and methanogenic pathway upon temperature changes is consistent with previous studies on sediment (Conrad, 1999; Glissmann et al., 2004), rice soil (Fey and Conrad, 2000; Peng et al., 2008) and high arctic peat (Høj et al., 2008). Thus, it appears that the shift of methanogen community and methanogenic pathway in response to temperature change is ubiquitous across ecosystems.

In seasonality studies under field conditions, other factors like vegetation growth, substrate availability and water level could also be important driving forces for the shift of methanogen community and methanogenesis (Juottonen et al., 2008). Temperature sensitivity factor of methanogenic activity has not been determined in previous studies. But in the study on boreal fen, it was shown that the relative abundance of Methanosarcinaceae increased while the hydrogenotrophic Methanomicrobiales-associated fen cluster (FC) was decreased in 
winter compared with summer (Juottonen et al., 2008). This shift of community composition was accompanied with a markedly enhanced temperature response for potential $\mathrm{CH}_{4}$ production in winter soil sample relative to summer sample. If similar pattern of temperature sensitivity as revealed in this study and that in boreal fen exists ubiquitously in cold environments, large increase of global $\mathrm{CH}_{4}$ emissions may eventually occur in a warming climate.

In summary, we showed that temperature responses of $\mathrm{CH}_{4}$ production in a Zoige wetland soil sample displayed a high sensitivity in the low temperature range and a modest sensitivity under mesophilic conditions. This change in sensitivity was correlated with shifts of methanogen community and methanogenic pathway. We have to indicate that only one soil sample was tested in the present study, hence representing only a snapshot of temperature sensitivity of methanogens in Zoige wetland. Further researches shall be necessary to elucidate the mechanisms of this pathway-dependent temperature sensitivity across different ecosystems and take it into account in the future modeling and prediction of climate change impacts and feedbacks.

\section{ACKNOWLEDGMENTS}

This study was partly supported by the National Basic Research Program of China (2011CB100505) and the National Natural Science Foundation of China (41130527).

\section{SUPPLEMENTARY MATERIAL}

The Supplementary Material for this article can be found online at: http://www.frontiersin.org/journal/10.3389/fmicb.2015. 00131/abstract

\section{REFERENCES}

Bond-Lamberty, B., and Thomson, A. (2010). Temperature-associated increases in the global soil respiration record. Nature 464, 579-582. doi: 10.1038 /nature 08930

Cai, Y., Lang, H., and Wang, X. (1965). Mires of Zoige Plateau. Beijing: Science Press.

Chen, H., Wu, N., Gao, Y., Wang, Y., Luo, P., and Tian, J. (2009a). Spatial variations on methane emissions from Zoige alpine wetlands of southwest China. Sci. Total Environ. 407, 1097-1104. doi: 10.1016/j.scitotenv.2008. 10.038

Chen, H., Wu, N., Wang, Y., Zhu, D., Yang, G., Gao, Y., et al. (2013a). Interannual variations of methane emission from an open fen on the QinghaiTibetan Plateau: a three-year study. PLoS ONE 8:e53878. doi: 10.1371/journal.pone. 0053878

Chen, H., Wu, N., Yao, S., Gao, Y., Wang, Y., Tian, J., et al. (2009b). Diurnal variation of methane emissions from an alpine wetland on the eastern edge of Qinghai-Tibetan Plateau. Environ. Monit. Assess. 164, 21-28. doi: 10.1007/s10661-009-0871-3

Chen, H., Zhu, Q. A., Peng, C., Wu, N., Wang, Y., Fang, X., et al. (2013b). Methane emissions from rice paddies natural wetlands, and lakes in China: synthesis and new estimate. Glob. Chang. Biol. 19, 19-32. doi: 10.1111/gcb.12034

Chin, K. J., Lukow, T., and Conrad, R. (1999). Effect of temperature on structure and function of the methanogenic archaeal community in an anoxic rice field soil. Appl. Environ. Microbiol. 65, 2341-2349.

Conrad, R. (1999). Contribution of hydrogen to methane production and control of hydrogen concentrations in methanogenic soils and sediments. FEMS Microbiol. Ecol. 28, 193-202. doi: 10.1111/j.1574-6941.1999. tb00575.x

Conrad, R. (2009). The global methane cycle: recent advances in understanding the microbial processes involved. Environ. Microbiol. Rep. 1, 285-292. doi: 10.1111/j.1758-2229.2009.00038.x
Conrad, R., Klose, M., and Noll, M. (2009). Functional and structural response of the methanogenic microbial community in rice field soil to temperature change. Environ. Microbiol. 11, 1844-1853. doi: 10.1111/j.1462-2920.2009.01909.x

Davidson, E. A., and Janssens, I. A. (2006). Temperature sensitivity of soil carbon decomposition and feedbacks to climate change. Nature 440, 165-173. doi: 10.1038 /nature 04514

Fey, A., and Conrad, R. (2000). Effect of temperature on carbon and electron flow and on the archaeal community in methanogenic rice field soil. Appl. Environ. Microbiol. 66, 4790-4797. doi: 10.1128/AEM.66.11.4790-4797.2000

Galand, P. E., Fritze, H., Conrad, R., and Yrjala, K. (2005). Pathways for methanogenesis and diversity of methanogenic archaea in three boreal peatland ecosystems. Appl. Environ. Microbiol. 71, 2195-2198. doi: 10.1128/AEM.71.4.21952198.2005

Galand, P. E., Fritze, H., and Yrjala, K. (2003). Microsite-dependent changes in methanogenic populations in a boreal oligotrophic fen. Environ. Microbiol. 5, 1133-1143. doi: 10.1046/j.1462-2920.2003.00520.x

Galand, P. E., Saarnio, S., Fritze, H., and Yrjala, K. (2002). Depth related diversity of methanogen archaea in Finnish oligotrophic fen. FEMS Microbiol. Ecol. 42, 441-449. doi: 10.1111/j.1574-6941.2002.tb01033.x

Glissmann, K., Chin, K. J., Casper, P., and Conrad, R. (2004). Methanogenic pathway and archaeal community structure in the sediment of eutrophic Lake Dagow: effect of temperature. Microb. Ecol. 48, 389-399. doi: 10.1007/s00248003-2027-2

Godin, A., Mclaughlin, J. W., Webster, K. L., Packalen, M., and Basiliko, N. (2012). Methane and methanogen community dynamics across a boreal peatland nutrient gradient. Soil Biol. Biochem. 48, 96-105. doi: 10.1016/j.soilbio.2012.01.018

Good, I. J. (1953). The population frequencies of species and the estimation of population parameters. Biometrika 40, 237-264. doi: 10.1093/biomet/40.3-4.237

Hartley, I. P., Armstrong, A. F., Murthyw, R., Barron-Gafford, G., Ineson, P., and Atkin, O. K. (2006). The dependence of respiration on photosynthetic substrate supply and temperature: integrating leaf, soil and ecosystem measurements. Glob. Chang. Biol. 12, 1954-1968. doi: 10.1111/j.1365-2486.2006.01214.x

He, G., Li, K., Liu, X., Gong, Y., and Hu, Y. (2014). Fluxes of methane, carbon dioxide and nitrous oxide in an alpine wetland and an alpine grassland of the Tianshan Mountains, China. J. Arid Land 6, 717-724. doi: 10.1007/s,40333-0140070-0

Høj, L., Olsen, R. A., and Torsvik, V. L. (2008). Effects of temperature on the diversity and community structure of known methanogenic groups and other archaea in high Arctic peat. ISME J. 2, 37-48. doi: 10.1038/ismej. 2007.84

IPCC: Climate Change. (2014). Mitigation of Climate Change. Working Group III Contribution to the IPCC Fifth Assessment Report. Avaliable online at: http://www.mitigation2014.org

Juottonen, H., Tuittila, E.-S., Juutinen, S., Fritze, H., and Yrjala, K. (2008). Seasonality of rDNA- and rRNA-derived archaeal communities and methanogenic potential in a boreal mire. ISME J. 2, 1157-1168. doi: 10.1038/ismej.2008.66

Kanta Gaihre, Y., Wassmann, R., Tirol-Padre, A., Villegas-Pangga, G., Aquino, E., and Kimball, B. A. (2014). Seasonal assessment of greenhouse gas emissions from irrigated lowland rice fields under infrared warming. Agric. Ecosyst. Environ. 184, 88-100. doi: 10.1016/j.agee.2013.11.024

Karhu, K., Auffret, M. D., Dungait, J. A. J., Hopkins, D. W., Prosser, J. I., Singh, B. K., et al. (2014). Temperature sensitivity of soil respiration rates enhanced by microbial community response. Nature 513, 81-84. doi: 10.1038/nature 13604

Kirschke, S., Bousquet, P., Ciais, P., Saunois, M., Canadell, J. G., Dlugokencky, E. J., et al. (2013). Three decades of global methane sources and sinks. Nat. Geosci. 6, 813-823. doi: 10.1038/ngeo 1955

Liu, D. Y., Ding, W. X., Jia, Z. J., and Cai, Z. C. (2011). Relation between methanogenic archaea and methane production potential in selected natural wetland ecosystems across China. Biogeosciences 8, 329-338. doi: 10.5194/bg-8329-2011

Lueders, T., and Friedrich, M. (2000). Archaeal population dynamics during sequential reduction processes in rice field soil. Appl. Environ. Microbiol. 66, 2732-2742. doi: 10.1128/AEM.66.7.2732-2742.2000

Lueders, T., Manefield, M., and Friedrich, M. W. (2004). Enhanced sensitivity of DNA-and rRNA-based stable isotope probing by fractionation and quantitative analysis of isopycnic centrifugation gradients. Environ. Microbiol. 6, 73-78. doi: 10.1046/j.1462-2920.2003.00536.x 
Ma, K., Conrad, R., and Lu, Y. H. (2012). Responses of methanogen mcrA genes and their transcripts to an alternate dry/wet cycle of paddy field soil. Appl. Environ. Microbiol. 78, 445-454. doi: 10.1128/AEM.06934-11

Macdonald, J. A., Fowler, D., Hargreaves, K. J., Skiba, U., Leith, I. D., and Murray, M. B. (1998). Methane emission rates from a northern wetland; response to temperature, water table and transport. Atmos. Environ. 32, 3219-3227. doi: 10.1016/S1352-2310(97)00464-0

Mahecha, M. D., Reichstein, M., Carvalhais, N., Lasslop, G., Lange, H., Seneviratne, S. I., et al. (2010). Global convergence in the temperature sensitivity of respiration at ecosystem level. Science 329, 838-840. doi: 10.1126/science.1189587

Noll, M., Matthies, D., Frenzel, P., Derakshani, M., and Liesack, W. (2005). Succession of bacterial community structure and diversity in a paddy soil oxygen gradient. Environ. Microbiol. 7, 382-395. doi: 10.1111/j.14622920.2005.00700.x

Peng, J., Lu, Z., Rui, J., and Lu, Y. (2008). Dynamics of the methanogenic archaeal community during plant residue decomposition in an anoxic rice field soil. Appl. Environ. Microbiol. 74, 2894-2901. doi: 10.1128/AEM.00070-08

Rui, J., Peng, J., and Lu, Y. (2009). Succession of bacterial populations during plant residue decomposition in rice field soil. Appl. Environ. Microbiol. 75, 4879-4886. doi: 10.1128/AEM.00702-09

Rui, J., Qiu, Q., and Lu, Y. (2011). Syntrophic acetate oxidation under thermophilic methanogenic condition in Chinese paddy field soil. FEMS Microbiol. Ecol. 77, 264-273. doi: 10.1111/j.1574-6941.2011.01104.x

Sabrekov, A. F., Runkle, B. R. K., Glagolev, M. V., Kleptsova, I. E., and Maksyutov, S. S. (2014). Seasonal variability as a source of uncertainty in the West Siberian regional $\mathrm{CH}_{4}$ flux upscaling. Environ. Res. Lette. 9. doi: 10.1088/17489326/9/4/045008

Schloss, P. D., and Handelsman, J. (2005). Introducing DOTUR, a computer program for defining operational taxonomic units and estimating species richness. Appl. Environ. Microbiol. 71, 1501-1506. doi: 10.1128/AEM.71.3.15011506.2005

Steinberg, L. M., and Regan, J. M. (2008). Phylogenetic comparison of the methanogenic communities from an acidic, oligotrophic fen and an anaerobic digester treating municipal wastewater sludge. Appl. Environ. Microbiol. 74, 6663-6671. doi: 10.1128/AEM.00553-08

Tian, J., Chen, H., Dong, X., and Wang, Y. (2012a). Relationship between archaeal community structure and vegetation type in a fen on the Qinghai-Tibetan Plateau. Biol. Fertil. Soils 48, 349-356. doi: 10.1007/s00374-011-0597-6

Tian, J., Zhu, Y., Kang, X., Dong, X., Li, W., Chen, H., et al. (2012b). Effects of drought on the archaeal community in soil of the Zoige wetlands of the QinghaiTibetan plateau. Eur. J. Soil Biol. 52, 84-90. doi: 10.1016/j.ejsobi.2012.07.003

Van Hulzen, J. B., Segers, R., Van Bodegom, P. M., and Leffelaar, P. A. (1999). Temperature effects on soil methane production: an explanation for observed variability. Soil Biol. Biochem. 31, 1919-1929. doi: 10.1016/S00380717(99)00109-1

Wei, D., Xu, R., Liu, Y., Wang, Y., and Wang, Y. (2014). Three-year study of $\mathrm{CO}_{2}$ efflux and $\mathrm{CH}_{4} / \mathrm{N}_{2} \mathrm{O}$ fluxes at an alpine steppe site on the central Tibetan Plateau and their responses to simulated N deposition. Geoderma 232, 88-96. doi: 10.1016/j.geoderma.2014.05.002
Yang, G., Chen, H., Wu, N., Tian, J., Peng, C., Zhu, Q., et al. (2014). Effects of soil warming, rainfall reduction and water table level on $\mathrm{CH}_{4}$ emissions from the Zoige peatland in China. Soil Biol. Biochem. 78, 83-89. doi: 10.1016/j.soilbio.2014.07.013

Yrjala, K., Tuomivirta, T., Juottonen, H., Putkinen, A., Lappi, K., Tuittila, E.-S., et al. (2011). $\mathrm{CH}_{4}$ production and oxidation processes in a boreal fen ecosystem after long-term water table drawdown. Glob. Chang. Biol. 17, 1311-1320. doi: 10.1111/j.1365-2486.2010.02290.x

Yuan, Q., and Lu, Y. (2009). Response of methanogenic archaeal community to nitrate addition in rice field soil. Environ. Microbiol. Rep. 1, 362-369. doi: 10.1111/j.1758-2229.2009.00065.x

Yvon-Durocher, G., Allen, A. P., Bastviken, D., Conrad, R., Gudasz, C., St-Pierre, A., et al. (2014). Methane fluxes show consistent temperature dependence across microbial to ecosystem scales. Nature 507, 488-491. doi: 10.1038/nature 13164

Yvon-Durocher, G., Caffrey, J. M., Cescatti, A., Dossena, M., Del Giorgio, P., Gasol, J. M., et al. (2012). Reconciling the temperature dependence of respiration across timescales and ecosystem types. Nature 487, 472-476. doi: 10.1038 /nature11205

Zhang, G., Jiang, N., Liu, X., and Dong, X. (2008a). Methanogenesis from methanol at low temperatures by a novel psychrophilic methanogen, "Methanolobus psychrophilus" sp nov., prevalent in Zoige wetland of the Tibetan plateau. Appl. Environ. Microbiol. 74, 6114-6120. doi: 10.1128/AEM. 01146-08

Zhang, G., Tian, J., Jiang, N., Guo, X., Wang, Y., and Dong, X. (2008b). Methanogen community in Zoige wetland of Tibetan plateau and phenotypic characterization of a dominant uncultured methanogen cluster ZC-I. Environ. Microbiol. 10, 1850-1860. doi: 10.1111/j.1462-2920.2008.01606.x

Zou, D., and Gao, K. (2013). Thermal acclimation of respiration and photosynthesis in the marine macroalga Gracilaria lemaneiformis (Gracilariales, Rhodophyta). J. Phycol. 49, 61-68. doi: 10.1111/jpy.12009

Conflict of Interest Statement: The authors declare that the research was conducted in the absence of any commercial or financial relationships that could be construed as a potential conflict of interest.

Received: 05 November 2014; accepted: 04 February 2015; published online: 19 February 2015.

Citation: Fu L, Song T and Lu Y (2015) Snapshot of methanogen sensitivity to temperature in Zoige wetland from Tibetan plateau. Front. Microbiol. 6:131. doi: 10.3389/ fmicb.2015.00131

This article was submitted to Terrestrial Microbiology, a section of the journal Frontiers in Microbiology.

Copyright (C) $2015 \mathrm{Fu}$, Song and Lu. This is an open-access article distributed under the terms of the Creative Commons Attribution License (CC BY). The use, distribution or reproduction in other forums is permitted, provided the original author(s) or licensor are credited and that the original publication in this journal is cited, in accordance with accepted academic practice. No use, distribution or reproduction is permitted which does not comply with these terms. 